\title{
Analisis Komponen Yield Minyak Mikro Alga Hijau Dengan Medium Detmer
}

\author{
Bahagia $^{1, *}$ Vera Viena ${ }^{2}$ \\ ${ }^{1,2}$ Program Studi Teknik Lingkungan Fakultas Teknik, Universitas Serambi Mekkah \\ Jln. Unmuha Batoh Banda Aceh \\ *Koresponden email: bahagia@serambimekkah.ac.id
}

Diterima: 12 Maret 2019

Disetujui: 29 Maret 2019

\begin{abstract}
This study examines $\mathrm{CO} 2$ for the growth of green microalgae by cultivating algal strains in a tank type reactor or fermentor. The study included optimization of the productivity of green algae in the capture of $\mathrm{CO} 2$ which can be used as a greenhouse gas catcher. Green algae were isolated from several waters in Banda Aceh and Aceh Besar. The microalgae species of this isolation and its identified species were subsequently cultivated in a tank-shaped cultivation (cultivation) container with 4 flourescent lamps ( $2 \times 8$ watts; 4x8 watts) installed on the outside side of the tank. This study evaluated the comparison of the growth of aerated microalgae $\mathrm{O} 2$ (1.25 liters / minute) with fixation of $\mathrm{CO} 2$ ( 1 and 2 liters / minute). The capture of $\mathrm{CO} 2$ into carbon dioxide is done by looking at the growing biomass, and the yield content of oil in biomass. The results showed that there were significant differences in the growth patterns of microalgae given $\mathrm{O} 2$ aeration and $\mathrm{CO} 2$ fixation. Modified \& CHU 13 Detmer Modified media does not provide a significant difference to algal growth. With a large intensity of light with a medium that is sufficient to increase the growth of microalgae until it reaches the death phase. Component analysis by Chromatography Gas Mass Spectrometry (GC-MS) shows that the largest component in vegetable oils from green microalgae is Palmatic acid (9.36\%), Thiogeraniol (24.63\%), Cyclopropane Methanol (2.45\%), Farnesol (2.39\%), Trimethyl (2.78\%) and Dodencadien (5.06\%).
\end{abstract}

Keywords: catchment, greenhouse gases, green microalgae, isolation, cultivation, biomass

\begin{abstract}
Abstrak
Penelitian tentang $\mathrm{CO} 2$ untuk pertumbuhan mikroalga hijau dengan membudidayakan strain alga dalam reaktor atau fermentor tipe tangki. Kajian mencakup optimasi produktivitas alga hijau dalam penangkapan $\mathrm{CO} 2$ yang dapat dimanfaatkan sebagai penangkap gas rumah kaca. Alga hijau diisolasi dari beberapa perairan di Banda Aceh dan Aceh Besar. Spesies mikroalga hasil isolasi dan telah diidentifikasi jenisnya ini, selanjutnya dikultivasi dalam wadah cultivation (budidaya) berbentuk tangki yang disinari dengan 4 buah lampu flourescent (2x8 watt; $4 \mathrm{x} 8$ watt) terpasang disisi luar tangki. Penelitian mengevaluasi perbandingan pertumbuhan mikroalga aerasi $\mathrm{O} 2$ (1,25 liter/menit) dengan fiksasi CO2 (1 dan 2 liter/menit). Penangkapan CO2 menjadi karbondioksida dengan melihat biomassa yang tumbuh, dan kandungan yield minyak dalam biomassa. Hasil penelitian menunjukkan bahwa terjadi perbedaan yang nyata terhadap pola pertumbuhan mikroalga yang diberikan aerasi O2 dan fiksasi CO2. Media Detmer Modified \& CHU 13 Modified tidak memberikan perbedaan yang signifikan terhadap pertumbuhan alga. Dengan intensitas cahaya yang besar dengan medium yang cukup akan meningkatkan pertumbuhan mikroalga hingga mencapai fase kematian. Analisa komponen dengan Kromatografi Gas Mass Spectrometry (GC-MS) menunjukkan komponen terbesar dalam minyak nabati dari mikroalga hijau adalah Palmatic acid (9,36\%), Thiogeraniol (24,63\%), Cyclopropane Methanol (2,45\%), Farnesol (2,39\%), Trimethyl $(2,78 \%)$ dan Dodencadien (5,06 \%).
\end{abstract}

Kata kunci: penangkap (fixation), gas rumah kaca (GRK), mikroalga hijau, isolasi, kultivasi, biomassa

\section{Pendahuluan}

Sebagian besar minyak bumi dan gas alam diyakini berasal dari alga yang hidup di lautan kuno dan yang selanjutnya mengalami deposisi dan diikuti proses transformasi kimia dibawah pengaruh geologis selama berjuta-juta tahun. Minyak bumi terdiri dari hidrokarbon cair yang tersusun oleh atom karbon dan hidrogen. Paling tidak $80 \%$ beratnya merupakan karbon dan sisanya adalah hidrogen, dan sekitar 5\% lainnya dapat terdiri dari sulfur dan oksigen. Kapasitas panas hasil pembakaran minyak bumi relatif tinggi dikarenakan sifat cairnya dan hampir sebanding nilai 
pembakaran batubara. Berdasarkan kondisi produksi minyak bumi tahun 1998 sebesar 64,2 juta barel per hari, diperkirakan total cadangan minyak bumi terbukti (proven) akan habis dalam waktu 40 tahun.

Mikroalga adalah mikroorganisme fotosintetik dengan morfologi sel yang bervariasi, baik uni-selular maupun multiselular (membentuk koloni kecil). Sebagian besar mikroalga tumbuh secara fototrofik, meskipun tidak sedikit jenis yang mampu tumbuh secara heterotrofik. Ganggang hijau-biru prokariotik (cyanobacteria) juga termasuk dalam kelompok mikroalga. Dalam Bergey's Manual of Systematic Bacteria, kelompok mikroorganisme ini ditempatkan bersama-sama dengan kelas Oxyphotobacteria, dalam divisi Gracilicutes. Hingga saat ini tidak kurang dari 30.000 jenis mikroalga telah dikenal dan dipelajari secara intensif (Taylor, 1967).

Di Indonesia sendiri ada ratusan jenis mikroalga (Atmadja dkk., 1996). Mikroalga merupakan tanaman yang paling efisien dalam menangkap dan memanfaatkan energi matahari dan $\mathrm{CO}_{2}$ untuk keperluan fotosintesis. Selain itu, $\mathrm{CO}_{2}$ dimanfaatkan untuk meningkatkan produktivitas mikroalga (Davis, 1981). Keberadaan mikroalga sangat membantu dalam pencegahan terjadinya pemanasan global. $\mathrm{C}_{2}$ hasil industri yang terbuang, ditampung dan dimanfaatkan untuk pertumbuhan mikroalga. Terdapat empat kelompok mikroalga yang sejauh ini dikenal di dunia, yakni diatom (Bacillariophyceae), ganggang hijau (Chlorophyceae), ganggang emas (Chrysophyceae), dan ganggang biru (Cyanophyceae). Keempat kelompok mikroalga tersebut bisa dimanfaatkan sebagai bahan baku bioenergi (Davis, 1981).

Mikroalga merupakan tumbuhan paling primitif yang umumnya hanya terdiri dari satu sel. Mikroalga merupakan sel yang menggunakan energi matahari dalam fotosintesis untuk mengubah karbondioksida menjadi bahan bakar minyak, pangan, pakan, maupun senyawa bioaktif bernilai tinggi (Spolaore dkk., 2006).

Mikroalga dapat menyediakan komponen bahan bakar minyak yang dapat diperbaharui. Senyawa metana dapat diproduksi dari biomassa alga secara pencernaan anaerobik (tanpa oksigen), hidrokarbon dan triasilgliserol dihasilkan dari mikroalga minyak (Spolaore dkk, 2006; Gavrilescu dan Chisti, 2005). Ide penggunaan mikroalga sebagai penangkapan $\mathrm{CO}_{2}$ dan penghasil bahan bakar minyak bukan merupakan suatu hal yang baru, namun saat ini hal tersebut perlu diperhatikan secara sungguh-sungguh, mengingat semakin meningkatnya produksi gas rumah kaca yang mengakibatkan terjadinya pemanasan global (Gavrilescu dan Chisti, 2005).

Penelitian ini bertujuan mengkaji penangkapan
$\mathrm{CO}_{2}$ untuk pertumbuhan mikroalga hijau yang diperoleh dari beberapa lokasi di Banda Aceh dan Aceh Besar. Mikroalga tersebut dibudidayakan dalam reaktor tipe tangki sebagai usaha penangkapan $\mathrm{CO}_{2}$ dan kandungan minyak dalam biomassa. Kajian mencakup optimasi produktivitas alga dalam menangkap $\mathrm{CO}_{2}$ dengan menentukan Biomassa kering mikroalga (g-BK/L) dan mengkaji kandungan minyak dari biomassa yang tumbuh.

\section{Tinjauan Pustaka}

Mikro alga merupakan tumbuhan tak berpembuluh yang tumbuh melekat pada substrat dasar laut, tumbuhan tersebut tidak memiliki akar, batang, daun, bunga, dan biji sejati (Sumich, 1979). Berdasarkan kandungan pigmennya rumput laut merupakan makroalgae bentik yang terdiri dari jenis-jenis yang termasuk divisio Rhodophyta (alga merah), Phaeophyta (alga coklat) dan Chlorophyta (alga hijau). Rumput laut umumnya tumbuh melekat pada suatu substrat (Atmadja dkk, 1996).

Rumput laut atau seaweed termasuk tumbuhan berthallus yang banyak dijumpai hampir di seluruh perairan pantai Indonesia, terutama di pantai yang mempunyai rataan terumbu karang. Di dalam perairan rumput laut menempati posisi sebagai produsen primer yang menyokong kehidupan biota lain pada tropik level yang lebih tinggi. Rumput laut umumnya hidup di dasar laut dan substratnya dapat berupa pasir, pecahan karang (gravel), karang mati, serta bendabenda keras yang terendam di dasar laut.

Mikro alga hidup di laut yang tidak memiliki akar, batang dan daun sejati dan pada umumnya hidup di dasar perairan dan menempel pada substrat (benda lain). Fungsi akar (holdfast) pada rumput laut bukan sebagai penyerap makan melainkan sebagai alat pelekat pada substrat, karena tidak memiliki akar, batang dan daun seperti umumnya pada tanaman, maka rumput laut digolongkan ke dalam tumbuhan tingkat rendah (Thallophyta).

Salah satu mekanisme fotosintesis yang diharapkan dapat berperan adalah melalui siklus kehidupan mikroalga. Mulai tahun 1978 sampai 1996, telah meneliti penggunaan algae sebagai sumber biodiesel dan memperkirakan subtitusi mencapai $50 \%$ dapat dicapai dari sumber algae tersebut (Davis, C.C. 1981). Mikroalga memiliki beberapa karakteristik yang atraktif, antara lain:

a. Melalui metabolisme sel, mikroalga menghasilkan minyak nabati dan sel-sel matinya dapat dimanfaatkan juga sebagai sumber energi melalui proses konversi kimia;

b. Biaya pemanenan dan transportasi mikroalga 
ke lokasi produksi minyak nabati relatif murah dibandingkan dengan biomassa lainnya seperti kayu dan produk pertanian;

c. Karena ukurannya relatif kecil maka mikroalga dapat dengan mudah diolah secara kimiawi;

d. Alga dapat tumbuh dengan mudah pada kondisikondisi yang tidak cocok untuk tanaman pertanian biasa; dan

e. Mikroalga dapat berperan sebagai penangkap (fixation) gas rumah kaca atau $\mathrm{CO}_{2}$ di udara, sehingga berperan juga dalam menurunkan level $\mathrm{CO}_{2}$ yang dianggap sebagai penyebab pemanasan global.

Sumber energi alternatif sepanjang garis pantai dan bentangan perairan laut ini terkandung kekayaan sumberdaya alam yang berlimpah seperti ikan, rumput laut, bakau, terumbu karang, dan lain sebagainya. Indonesia terdiri dari 17.508 pulau, dengan garis pantai sekitar $81.000 \mathrm{~km}$. Wilayah lautannya meliputi 5,8 juta $\mathrm{km}^{2}$ atau 70 persen dari total teritorial Indonesia (Dahuri dkk., 2001).

Mikroalga dapat berperan sebagai penangkap (fixation) gas rumah kaca atau $\mathrm{CO}_{2}$ di udara, sehingga berperan dalam menurunkan level $\mathrm{CO}_{2}$ yang dianggap sebagaipenyebabpemanasan global.Untukmemproduksi biomassa mikroalga dengan proses fotosintesis yang memerlukan cahaya, $\mathrm{CO}_{2}$, air dan garam anorganik (Nitrogen, Fosfor, Besi, Silikon), dan suhu harus dijaga sekitar $20-30^{\circ} \mathrm{C}$. Adanya supplai $\mathrm{CO}_{2}$ sebagai sumber karbon utama, pencahayaan dan nutrien dibutuhkan untuk pertumbuhan alga. Sebagaimana diketahui, banyak parameter yang menentukan produktivitas alga dalam budidayanya. $\mathrm{CO}_{2}$ yang diberikan berlebihan dapat mematikan mikroalga.

Banerjee dkk. (2002) melaporkan bahwa pertumbuhan alga yang lambat tidak semata-mata dampak suplai nutrien yang terbatas, tetapi juga akibat komitmen selsel untuk menghasilkan senyawa-senyawa minyak. Sedangkan Rao dkk. (2007) menemukan bahwa suplai $\mathrm{CO}_{2}$ mempengaruhi pertumbuhan sel, serta menentukan akumulasi dan komposisi asam lemak dan hidrokarbon pada mikroalga hijau. Diharapkan hasil penelitian ini akan memberikan kondisi optimum untuk pertumbuhan mikroalga isolat lokal yang memiliki potensi sebagai penangkapan $\mathrm{CO}_{2}$.

\section{Mikroalga sebagai Sumber Minyak Nabati}

Mikroalga mengandung lemak dan asam lemak sebagai komponen membran, produk simpanan, metabolit dan sumber energi. Komposisi kimia berbagai mikroalga diperlihatkan pada Tabel 1 . Minyak alga memiliki karakterisitik mirip dengan minyak nabati dan minyak ikan sehingga menjadi
Tabel 1. Komposisi kimiawi beberapa alga (\% basis kering)

\begin{tabular}{lcccc}
\hline Strain & Protein & Karbohidrat & Minyak & $\begin{array}{c}\text { Asam } \\
\text { Nukleat }\end{array}$ \\
\hline $\begin{array}{l}\text { Scenedesmus } \\
\text { obliquus }\end{array}$ & $50-56$ & $10-17$ & $12-14$ & $3-6$ \\
$\begin{array}{l}\text { Scenedesmus } \\
\text { dimorphus }\end{array}$ & $8-18$ & $21-52$ & $16-40$ & - \\
$\begin{array}{l}\text { Chlamydomona } \\
\text { sheinhardii }\end{array}$ & 48 & 17 & 21 & - \\
$\begin{array}{l}\text { Chlorella } \\
\text { vulgaris }\end{array}$ & $51-58$ & $12-17$ & $14-22$ & $4-5$ \\
$\begin{array}{l}\text { Spirogyra sp. } \\
\begin{array}{l}\text { Euglena } \\
\text { gracilis }\end{array}\end{array}$ & $6-20$ & $33-64$ & $11-21$ & - \\
$\begin{array}{l}\text { Prymnesium } \\
\text { parvum }\end{array}$ & $28-45$ & $14-18$ & $14-20$ & - \\
$\begin{array}{l}\text { Porphyridium } \\
\text { cruentum }\end{array}$ & $28-39$ & $40-57$ & $9-14$ & - \\
$\begin{array}{l}\text { Synechoccus } \\
\text { sp. }\end{array}$ & 63 & 15 & 11 & 5 \\
\hline
\end{tabular}

Sumber: Becker (1994).

sumber alternatif pengganti produk-produk dari minyak fosil (Princen, 1982). Ekstraksi langsung minyak mikroalga merupakan cara yang lebih efisien untuk mendapatkan energi dari mikroorganisme dibandingkan fermentasi biomassa alga menjadi metana atau methanol. Kandungan minyak dan asam lemak mikroalga bervariasi menurut kondisi budidaya.

\section{Metode Penelitian}

\subsection{Bahan}

Bahan yang digunakan pada penelitian ini adalah media kultur yang mengandung nutrien dan suplemen sesuai kebutuhan untuk pertumbuhan mikroalga diperlihatkan pada Tabel 2.

Komposisi mikro nutrien ditampilkan pada Tabel 3:

Medium Detmer merupakan media yang tersusun dalam satuan per liter yang kesemuanya dilarutkan sampai volume air $(1000 \mathrm{~mL})$ dan $\mathrm{pH}$ media diatur sekitar 7,5.

\subsection{Alat}

Wadah tipe tangki (acrylic) dilengkapi 4 lampu flourescent (masing-masing 8 watt), spektrofotometer,

Tabel 2. Komposisi medium CHU 13 modified

\begin{tabular}{lll}
\hline No & $\begin{array}{c}\text { Komposisi Medium CHU } \\
13 \text { modified }\end{array}$ & \multicolumn{1}{c}{ Berat } \\
\hline 1 & $\mathrm{NaNO}_{3}$ & $4 \mathrm{gr}$ \\
2 & $\mathrm{Na}_{2} \mathrm{HPO}_{4}$ & $0,08 \mathrm{gr}$ \\
3 & $\mathrm{MgSO}_{4}$ heptahidrat & $0,2 \mathrm{gr}$ \\
4 & $\mathrm{ZnCl}_{2}$ dihidrat & $0,107 \mathrm{gr}$ \\
5 & Ferri sulfat, & $0,02 \mathrm{gr}$ \\
6 & Asam sitrat, & $0,1 \mathrm{gr}$ \\
7 & $\mathrm{CoCl}_{3}$ dihidrat, dan & $0,107 \mathrm{gr}$ \\
8 & mikro nutrien & $1 \mathrm{ml}$ \\
\hline
\end{tabular}

Sumber: Largeau dkk. (1980) 
Tabel 3. Komposisi mikro

\begin{tabular}{|c|c|c|}
\hline $\begin{array}{c}\mathrm{N} \\
\mathrm{o}\end{array}$ & Komposisi nutrien mikro & Berat \\
\hline 1 & $\mathrm{H}_{3} \mathrm{BO}_{3}$ & $0,00572 \mathrm{gr}$ \\
\hline 2 & $\mathrm{ZnSO}_{4}$ heptahidrat, & $0,00044 \mathrm{gr}$ \\
\hline 3 & $\mathrm{MnCl}_{2}$ tetrahidrat, & 0,00367 gr \\
\hline 4 & $\mathrm{Na}_{2} \mathrm{MoO}_{4}$ & $0,000084 \mathrm{gr}$ \\
\hline 5 & $\mathrm{CuSO}_{4}$ pentahidrat & $0,00016 \mathrm{gr}$ \\
\hline 6 & $0,072 \mathrm{~N} \mathrm{H}_{2} \mathrm{SO}_{4}$ & 1 tetes \\
\hline
\end{tabular}

Sumber : Largeau dkk., (1980)

GC-MS (Gas Kromatografi Mass Spectrometry), mikroskop digital, autoclave, clean bench, timbangan analitik, centrifuge, pompa udara, petridish, gelas ukur, erlenmeyer $(100 \mathrm{ml}, 250 \mathrm{ml}, 500 \mathrm{ml}, 1000 \mathrm{ml})$, tabung $\mathrm{CO}_{2}$, regulator $\mathrm{CO}_{2}$, pipet volume, tabung kimia, kapas, tissu dan aluminium foil soxklet dan rotary evaporator.

\subsection{Metode}

Persiapan media dan culture alga hijau diperoleh dari penelitian pendahuluan sebelumnya yang berupa isolasi mikroalga dari beberapa lokasi di Banda Aceh dan Aceh Besar. Isolat tersebut dapat tumbuh dan berkembang dengan baik. Isolat selanjutnya dikultivasi dalam wadah cultivation (budidaya) berbentuk tangki yang disinari dengan 4 buah lampu flourescent (Philip; 2 x 8 watt, 4 x 8 watt) terpasang disisi luar tangki.

Mikroalga membutuhkan tiga komponen utama untuk pertumbuhan yaitu cahaya matahari, $\mathrm{CO}_{2}$, dan air (Oilgae, 2008). $\mathrm{CO}_{2}$ diperoleh secara komersial dari supplier gas yang selanjutnya $\mathrm{CO}_{2}$ difiksasi untuk proses fotosintesis (Moroney dan Somanchi, 1999). Penelitian ini merupakan riset lanjutan untuk perkembangbiakan mikroalga hijau (Green algae) lokal dengan perlakuan fiksasi $\mathrm{CO}_{2}$, untuk melihat efektivitas dan pertumbuhannya.

Pada riset lanjutan ini, sampel didapatkan dengan mengisolasi mikroalga dari stok sampel penelitian terbaik sebelumnya, yaitu sampel Tanjong Selamat.

Tabel 4. Komposisi Medium Detmer modified

\begin{tabular}{lll}
\hline No & $\begin{array}{c}\text { Komposisi Medium Detmer } \\
\text { modified }\end{array}$ & \multicolumn{1}{c}{ Berat } \\
\hline 1 & $\mathrm{NaNO}_{3}$, & $4 \mathrm{gr}$ \\
2 & $\mathrm{Na}_{2} \mathrm{HPO}_{4}$, & $0,08 \mathrm{gr}$ \\
3 & $\mathrm{MgSO}_{4}$ heptahidrat & $0,1 \mathrm{gr}$ \\
4 & $\mathrm{ZnCl}_{2}$ dihidrat & $0,01 \mathrm{gr}$ \\
5 & Ferri sulfat & $0,002 \mathrm{gr}$ \\
6 & $\mathrm{NaCl}_{7}$ & $0,01 \mathrm{gr}$ \\
8 & $\mathrm{Na}_{2}$-EDTA dan & $0,01 \mathrm{gr}$ \\
\hline
\end{tabular}

Sumber : Maeda dkk., (1998)

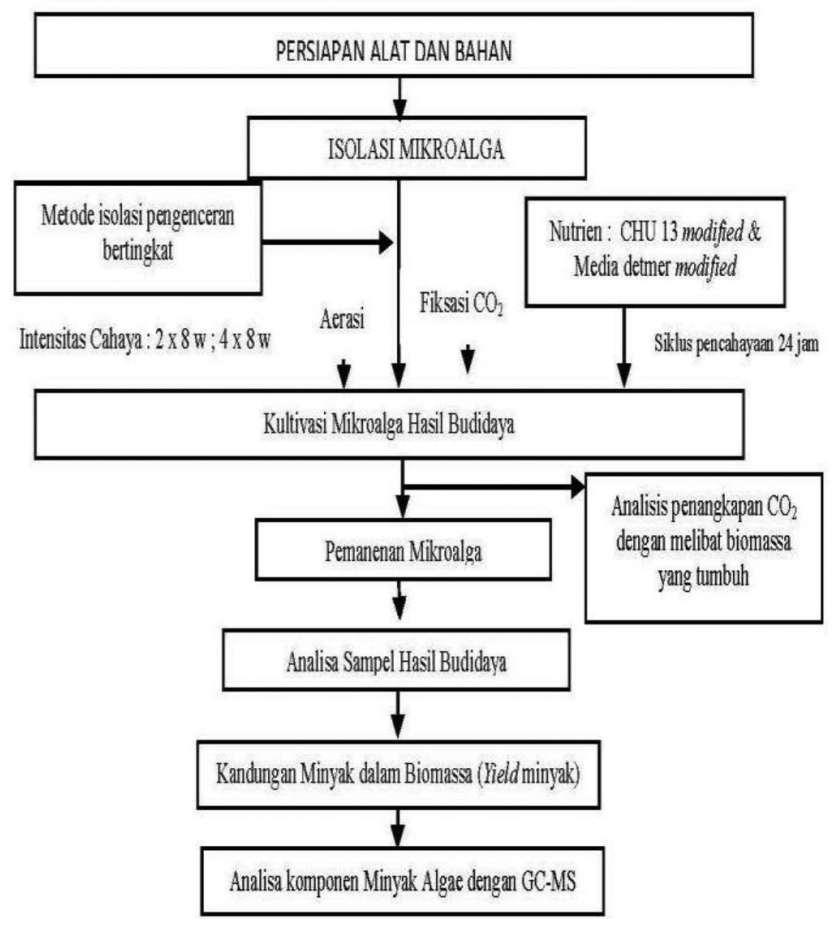

Gambar 1. Grand design percobaan

Sampel Tanjong Selamat menghasilkan sampel culture yang baik. Karakteristik lokasi sampel merupakan kolam terbuka dengan $\mathrm{pH}$ sekitar 7,7 - 8,5; tingkat salinitas $0,01 \%-0,02 \%$. Pengambilan sampel dilakukan dengan net plankton, kemudian sampel disentrifugasi dan ditanam dalam media kultur yaitu Detmer modified (DM) dan CHU 13 modified.

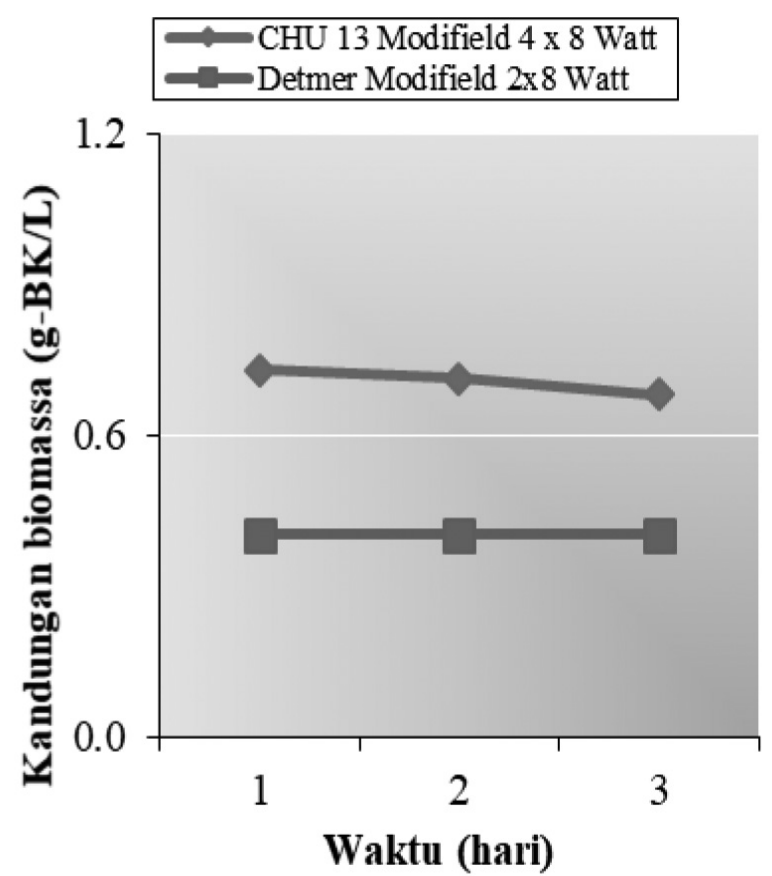

Gambar 2. Perolehan \% yield minyak atau lemak mikroalga terhadap intensitas cahaya, serta laju alir $\mathrm{CO}_{2} 2$ liter/menit, Kondisi : $\mathrm{T}=30^{\circ} \mathrm{C} ; \mathrm{pH}=7,5$ 


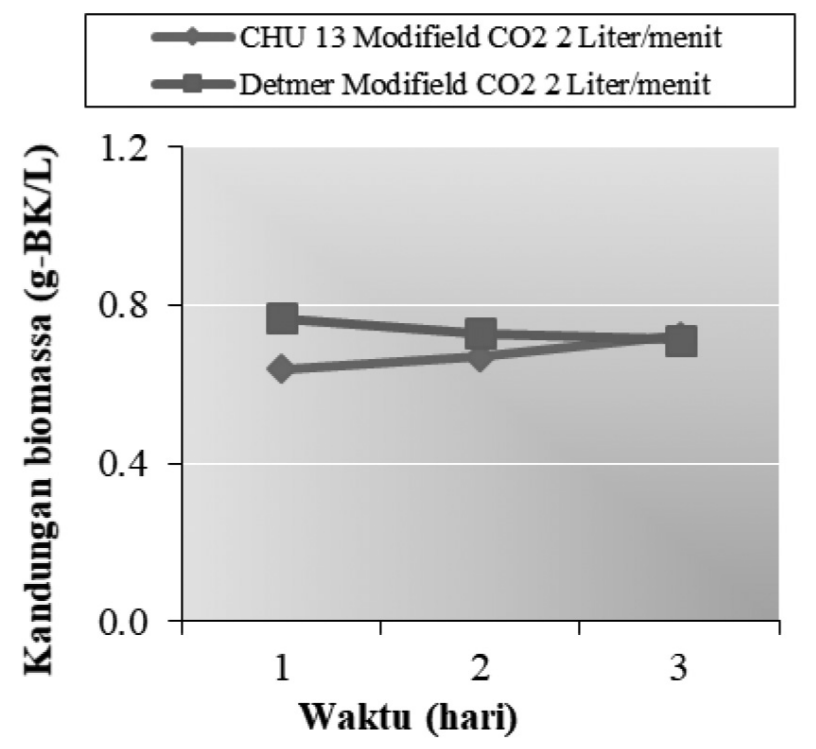

Gambar 3. Perolehan \% yield minyak atau lemak mikroalga terhadap media, serta laju alir $\mathrm{CO}_{2} 2$ liter/menit, Kondisi : $\mathrm{T}=$ $30{ }^{\circ} \mathrm{C} ; \mathrm{pH}=7,5$

\subsection{Prosedur Percobaan}

Grand design percobaan dengan melakukan analisis sampel penangkapan $\mathrm{CO}_{2}$ untuk melihat biomassa yang tumbuh, kandungan minyak (yield minyak) dan identifikasi komponen yang terkandung dalam minyak nabati mikroalga.

\section{Hasil Dan Pembahasan}

\subsection{Pengaruh Pencahayaan terhadap Yield}

Hasil penelitian seperti pada Gambar 2 diperoleh kandungan minyak atau lemak mikroalga dengan pelarut n-heksana pada intensitas cahaya $2 \times 8$ Watt diperoleh kandungan minyak atau lemak sebesar $1,191 \mathrm{gr} / \mathrm{L}$ dan yield minyak 40,05 \%, sedangkan untuk intensitas cahaya $4 \times 8$ Watt diperoleh kandungan minyak atau lemak sebesar $1,773 \mathrm{gr} / \mathrm{L}$ dan yield minyak $79 \%$. Perolehan kandungan minyak algae lebih besar cahaya $4 \times 8$ Watt.

Pencahayaan berpengaruh nyata dalam perolehan minyak atau lemak alga, sehingga pada pencahayaan $2 \times 8$ dan $4 \times 8$ Watt perolehan minyak atau lemak alga berbeda. Kesimpulan dari penelitian ini bahwa dengan intensitas cahaya lebih besar memberi pengaruh terhadap perolehan minyak atau lemak alga lebih besar. Sedangkan intensitas cahaya sedang memberi pengaruh terhadap perolehan minyak atau lemak sedikit.

\subsection{Pengaruh Media terhadap Yield}

Hasil penelitian seperti yang diilustrasikan pada Gambar 3 perolehan kandungan minyak atau lemak mikroalga dengan pelarut n-heksana pada mikroalga yang diberi media $\mathrm{CHU}$ modifield dan pencahayaan
$4 \times 8$ watt serta laju alir $\mathrm{CO}_{2} 2$ liter/menit diperoleh kandungan minyak atau lemak sebesar 0,772 gr dan yield minyak $72 \%$. Sedangkan untuk mikroalga yang diberi media Detner modifield dan pencahayaan $4 \mathrm{x} 8$ watt serta laju alir $\mathrm{CO}_{2} 2$ liter/menit diperoleh sebesar 1,988 gr dan yield minyak 71,36\%. Perolehan kandungan minyak algae diperlihatkan pada Gambar 3.

\subsection{Pengaruh $\mathrm{CO}_{2}$ dan $\mathrm{O}_{2}$ terhadap Yield}

Hasil penelitian seperti yang diilustrasikan pada Gambar 3 perolehan kandungan minyak atau lemak mikroalga dengan pelarut n-heksana pada mikroalga yang diberi aerasi $\mathrm{O}_{2}$ diperoleh kandungan minyak atau lemak sebesar $0,81 \mathrm{gr}$ dan yield minyak $50 \%$. Sedangkan untuk mikroalga yang diberi aerasi $\mathrm{CO}_{2}$ diperoleh sebesar 1,902 gr dan yield minyak $74 \%$.

Perolehan minyak atau lemak dari alga membuktikan alga memiliki kandungan minyak nabati yang jauh lebih besar dari tanaman lainnya. Mikroalga memiliki kandungan minyak yang komposisinya mirip seperti tanaman darat, bahkan untuk jenis tertentu mempunyai kandungan minyak cukup tinggi melebihi kandungan minyak tanaman darat, seperti kelapa, pohon jarak dan sawit. Hasil penelitian ini dapat disimpulan bahwa terjadi perbedaan yang nyata terhadap perolehan minyak atau lemak diberikan aerasi $\mathrm{O}_{2}$ dan fiksasi $\mathrm{CO}_{2}$ berkisar $25-75 \%$.

\subsection{Identifikasi senyawa minyak nabati menggunakan Gas Chromatography Mass Spectrometry (GC-MS)}

Analisa komponen yield minyak alga hijau di dengan menggunakan Kromatografi Gas Mass Spectrometry (GC-MS) ditunjukkan pada Gambar 5:

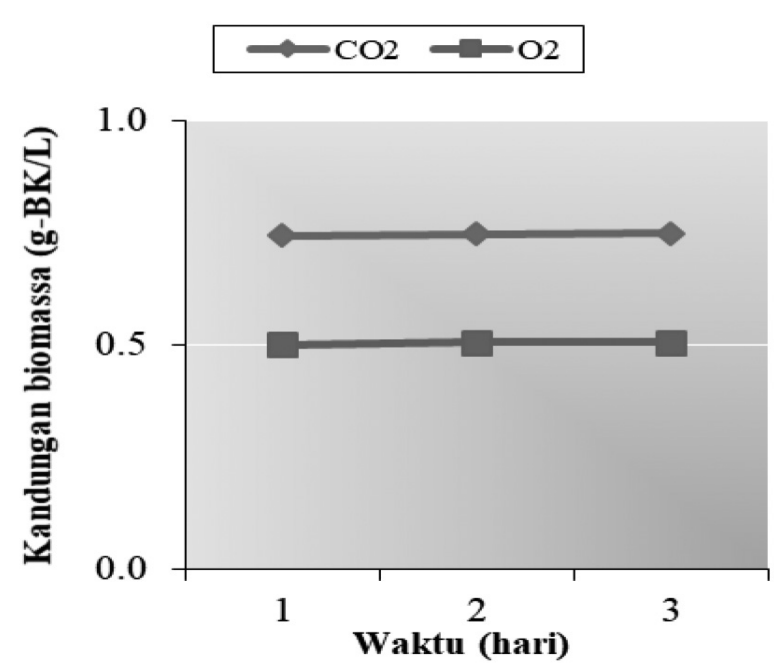

Gambar 4. Perolehan \% yield minyak atau lemak mikroalga dengan earasi $\mathrm{O}_{2}$ dan $\mathrm{CO}_{2}$ dengan intensitas cahaya 4x8 Watt, Kondisi : $\mathrm{T}=30^{\circ} \mathrm{C} ; \mathrm{pH}=7,5$ 


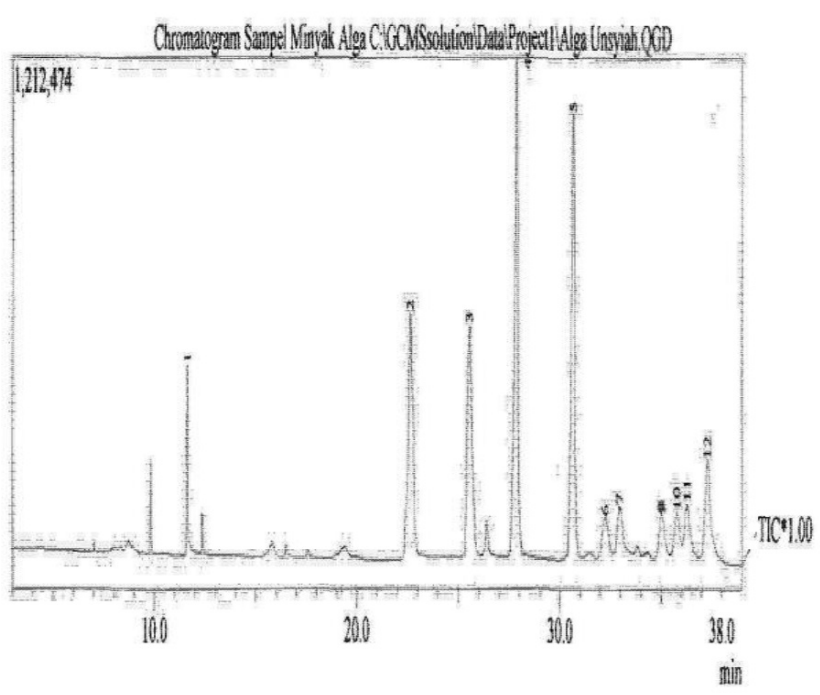

Gambar 5. Analisis komponen minyak nabati mikroalga dengan Kromatografi Gas Mass Spectrometry (GC-MS)

Identifikasi senyawa-senyawa yang terkandung dalam minyak nabati dari mikroalga dilakukan dengan menganalisa puncak-puncak yang memiliki persentasi tinggi. Berdasarkan Gambar 5 dapat diketahui diketahui bahwa ada 12 puncak pada analisa GC-MS dan 6 komponen terbesar dalam minyak nabati adalah Hexadecanoic acid (CAS)/Palmatic acid $(9,36 \%)$, Thiogeraniol $(12,17 \%)$, Thiogeraniol $(11,42 \%)$, Thiogeraniol $(24,63 \%)$, Thiogeraniol $(22,10 \%), \quad 2,2,4$-Trimethyl-3- $\quad(3,8,12,16-\quad$ Terta Methyl-Heptadeca-3,7,11,15-Tetraenyl-yclohex $(2,17$ \%), 2,2,4-Trimethyl-3-(3,8,12,16- Terta MethylHeptadeca-3,7,11,15-Tetraenyl-yclohex (2,79 \%), Cyclopropane Methanol (2,45 \%), Cis-Farnesol 2,6,10-Dedectrien-1-ol, 3,7,11- trimethyl (2,39 $\%)$ 2,2,4-Trimethyl-3-(3,8,12,16- Terta MethylHeptadeca-3,7,11,15-Tetraenyl-Cyclohex (2,93\%), 2,10-Dodencadien-1-ol, 3, 7, 11- trimethyl (5,06\%).

Berdasarkan data pada Gambar 5 dan Tabel 5 diketahui bahwa ada 12 puncak dan 6 komponen terbesar dalam minyak nabati pada analisa GC-MS. Puncak paling tinggi berarti kelipatan alga yang paling banyak diperoleh komponen. Berdasarkan ketinggian Retation Time (RT) diperlukan 37,30 menit untuk mendapatkan komponen 2,10-Dodencadien-1-ol, 3, 7, 11 - trimethyl. Senyawa dengan RT terendah yaitu 11,63 menit memberikan spektrum dengan puncak molekul palmitic acid. Spektrum MS dari minyak nabati alga diperoleh sebanyak 6 (enam) jenis minyak nabati mikroalga.

Palmitic acid (asam palmitat) sebagai ester gliserol yang terdapat dalam minyak nabati mikroaga dan lemak dengan rumus kimianya $\mathrm{CH}_{3}\left(\mathrm{CH}_{2}\right)_{14} \mathrm{COOH}$.
Asam lemak adalah asam karboksilat alifatik dengan berbagai hidrokarbon panjang pada salah satu ujung rantai bergabung ke terminal karboksil $(-\mathrm{COOH})$ kelompok di ujung lain. Rumus umum R-(CH2) n-COOH. Asam lemak jenuh tidak memiliki ikatan yang solid, sedangkan asam oleat merupakan asam lemak tak jenuh memiliki satu ikatan yang kuat (juga digambarkan sebagai olefin) dan asam lemak tak jenuh ganda seperti asam linolenat mengandung dua atau lebih ikatan padat. Asam laurat (juga disebut asam Dodecanoic) adalah asam utama dalam minyak kelapa (45 - 50 persen) dan minyak inti sawit (45 55 persen) (http://chemicalland21.com). Sedangkan komponen Triogeraniol atau 3,7-Dimethyl-2(trans),6octadiene-1-thiol larut dalam alkohol dan air.

Kandungan asam lemak (palmatic acid) yang ada dalam mikroalga merupakan sumber energi. Kandungan asam lemak tersebut dihasilkan melalui proses fotosintesis yang kemudian mengubah Karbon

Tabel 5. Hasil analisa GC-MS minyak nabati mikroalga

\begin{tabular}{|c|c|c|c|}
\hline Peak & $\begin{array}{l}\text { Retention } \\
\text { Time (RT) }\end{array}$ & Name & Persen \\
\hline 1 & 11,63 & Palmatic acid & 9,36 \\
\hline 2 & 22,65 & Thiogeraniol & 12,17 \\
\hline 3 & 25,54 & Thiogeraniol & 11,42 \\
\hline 4 & 27,86 & Thiogeraniol & 24,63 \\
\hline 5 & 30,66 & $\begin{array}{l}\text { Thiogeraniol } \\
\text { 2,2,4-Trimethyl-3- } \\
(3,8,12,16-\quad \text { Terta }\end{array}$ & 22,10 \\
\hline 6 & 32,56 & $\begin{array}{l}\text { Methyl-Heptadeca- } \\
\text { 3,7,11,15-Tetraenyl- } \\
\text { Cyclohex } \\
\text { 2,2,4-Trimethyl-3- } \\
(3,8,12,16-\quad \text { Terta }\end{array}$ & 2,17 \\
\hline 7 & 32,97 & $\begin{array}{l}\text { Methyl-Heptadeca- } \\
\text { 3,7,11,15-Tetraenyl- } \\
\text { Cyclohex }\end{array}$ & 2,78 \\
\hline 8 & 35,03 & $\begin{array}{l}\text { Cyclopropanemethanol, } \\
\text { Alpa, 2-Dimethyl-2-(4- } \\
\text { Methyl-3-Pentenyl)- }\end{array}$ & 2,45 \\
\hline 9 & 35,07 & $\begin{array}{l}\text { Cis-Farnesol 2,6,10- } \\
\text { Dedectrien-1-ol, 3,7,11- } \\
\text { trimethyl } \\
\begin{array}{l}\text { 2,2,4-Trimethyl-3- } \\
(3,8,12,16-\end{array}\end{array}$ & 2,39 \\
\hline 10 & 35,80 & $\begin{array}{l}\text { Methyl-Heptadeca- } \\
3,7,11,15 \text {-Tetraenyl- } \\
\text { Cyclohex } \\
\text { 2,2,4-Trimethyl-3- } \\
(3,8,12,16-\quad \text { Terta }\end{array}$ & 2,52 \\
\hline 11 & 36,31 & $\begin{array}{l}\text { Methyl-Heptadeca- } \\
\text { 3,7,11,15-Tetraenyl- } \\
\text { Cyclohex }\end{array}$ & 2,93 \\
\hline 12 & 37,31 & $\begin{array}{l}\text { 2,10-Dodencadien-1-ol, } \\
3,7,11 \text { - trimethyl }\end{array}$ & 5,06 \\
\hline & & Total & 100 \\
\hline
\end{tabular}


dioksida menjadi karbohidrat yang digunakan sebagai sumber makanan atau energi, dan menghasilkan hidrokarbon. Senyawa lain yang dihasilkan dari analisa dengan kromatografi gas, kemungkinan merupakan turunan alkyl ester dari masingmasing asam lemaknya. Analisa komponen dengan Kromatografi Gas (GC-MS) menunjukkan komponen terbesar dalam minyak nabati dari mikroalga hijau adalah Palmatic acid (9,36\%), Thiogeraniol (24,63\%), Cyclopropane Methanol (2,45 \%), Farnesol (2,39\%), dan Trimethyl (2,78\%) dan Dodencadien (5,06\%).

\section{Kesimpulan Dan Saran}

\subsection{Kesimpulan}

Berdasarkan hasil penelitian tentang penangkapan $\mathrm{CO}_{2}$ untuk pertumbuhan mikroalga hijau, kesimpulan yang dapat diperoleh adalah sebagai berikut :

1. Intensitas cahaya memberikan pengaruh terhadap pertumbuhan mikroalga dimana intensitas besar akan memberikan pertumbuhan lebih cepat hingga mencapai fase kematian. Sedangkan intensitas cahaya sedang memberi pengaruh pertumbuhan alga stabil hingga mencapai fase kematian.

2. Hasil analisis kandungan minyak diperoleh sebesar 1,372 gr/L dengan yield minyak $63 \%$ untuk medium CHU 13 modified, sedangkan medium Detmer modified diperoleh sebesar 1,903 gr/L dan yield minyak $76 \%$.

3. Analisa komponen dengan Kromatografi Gas Mass Spectrometry (GC-MS) menunjukkan bahan komponen terbesar dalam minyak nabati dari mikroalga hijau adalah Palmatic acid (9,36 \%), Thiogeraniol (24,63\%), Cyclopropane Methanol (2,45 \%), Farnesol (2,39\%), dan Trimethyl (2,78\%) dan Dodencadien (5,06\%).

\subsection{Saran}

1. Perlunya pengembangan mikroalga yang dilakukan lebih besar lagi sehingga dapat dilakukan peningkatan produksi minyak alga.

2. Perlu diteliti lebih lanjut dengan peralatan sederhana dan murah yang dapat membuat alga menjadi biodiesel dalam skala kecil, sehingga dapat membuka lapangan kerja bagi masyarakat.

\section{Daftar Pustaka}

Annonymous., 2011, http://chemicalland21.com/ industrialchem.htm

Atmadja, Kadi, Sulistidjo dan Rachmaniar. 1996. Pengenalan Jenis-Jenis Rumput Laut Indonesia. Puslitbang Oseanologi-LIPI, Jakarta.
Banerjee, A., Sharma, R., Chisti, Y. and Banerjee, U.C., 2002, "Botryococcus braunii: A Renewable Source of Hydrocarbons and Other Chemicals", Critical Reviews in Biotechnology, vol. 22, no. 3, hal. 245-279.

Becker, E.W., 1994, "Microalgae: biotechnology and microbiology", Cambrige Univ. Press, Cambrige, New York.

Davis, C.C. 1981, "The Marine and Freshwater Plankton”, Michigan State University Press, USA.

Dahuri, H.R., J. Rais, S.P. Ginting, dan J. Sitepu. 2001. Pengelolaan Sumberdaya Wilayah Pesisir dan Lautan Secara Terpadu. PT Pradnya Paramita. Jakarta.

Gavrilescu, M., and Chisti, Y., 2005, "Biotechnology a sustainable alternative for chemical industry", Biotechnol Adv., vol. 23, hal. 471-99.

Largeau C., Casadevall E., Berkaloff C. and DhamelincoutP., 1980, "Sites of accumulation and composition of hydrocarbons Phytochemistry”, vol. 19, hal. 1043-1051.

Maeda,S., Suhendrayatna, and Ohki, A., 1998, "Bioaccumulation of arsenic in D. magna fed a diet of arsenous freshwater algae", Proc. the $9^{\text {th }}$ Scientific Meeting (Hamamatsu) ISSN 09187685, pp. 193-196.

Moroney, J. V., A. Somanchi, 1999. "How do algae concentrate $\mathrm{CO}_{2}$ to increase the efficiensy of photosynhetic carbon fixation? Plant Physiol', 119 : 9-16.

Oilgae, 2008. "Algae Oil”, http://www.oilgae.com/ algae/oil, Tanggal akes 20 Februari 2008.

Princen, L.H., 1982, "Economic Botany", vol. 36, hlm 302-312.

Rao, R., Sarada, R. dan Ravishankar, G.A., 2007, "Influence of $\mathrm{CO}_{2}$ on Growth and Hydrocarbon Production in Botryococcus braunii", J. Microbiol. Biotechnol., vol. 17, no. 3, hal. 414419.

Sumich, J.L. 1979. An Introduction to The Biology of Marine Life Fifth Edition.WCB WM. C. Brown Publisher. United States of American, 2460 Kerper Bouleverd Dubuqua IA. 52001.

Spolaore, P., Joannis-Cassan, C., Duran, E. dan Isambert, A., 2006, "Commercial applications of microalgae”, J. Biosci Bioeng, vol. 101, hal. 87-96.

Taylor, W. R, 1967. Marine Algae Eastern Tropical and Subtropical Coast of The America Univ. Michigan Press. 